\section{Substrate Temperatures Influence Root and Shoot Growth of Southern Highbush and Rabbiteye Blueberries}

\author{
James M. Spiers \\ U.S. Department of Agriculture, Agricultural Research Service, Small Fruit \\ Research Station, Poplarville, MS 39470
}

Additional index words. Vaccinium spp., cultivars

\begin{abstract}
A greenhouse study was conducted to evaluate the influence of substrate temperatures $(16,27$, and $38 \mathrm{C})$ on root and shoot growth of six blueberry (Vaccinium spp.) clones (three clones each of two types). Between types, southern highbush (primarily $V$. corymbosum $\mathrm{L}$.) produced more roots and total growth than rabbiteye ( $V$. ashei Reade). Comparing clones, 'Gulfcoast' (southern highbush) was the most vigorous and 'Tifblue' (rabbiteye) the least vigorous. Each clone had a negative linear response to substrate temperatures in all growth characteristics. Root and shoot growth was best at 16C. This study indicates that both rabbiteye and southern highbush blueberries would respond favorably to cultural practices that lower soil temperatures during the summer growing season.
\end{abstract}

Blueberries have a fine, fibrous root system that is relatively shallow and devoid of root hairs (Eck, 1988). Abbott and Gough (1987) reported that roots of highbush blueberries grew throughout the year, but growth was greatly reduced in soil below $8 \mathrm{C}$. They found two periods of accelerated growth, the first in early June and the second in September. These periods occurred when soils were between 14 and $18 \mathrm{C}$, and root growth declined at soil temperatures below or above this range.

In a greenhouse study, Basiouny and Powell (1985) found that high (50C) soil temperatures enhanced the early shoot growth of young 'Tifblue' rabbiteye blueberries, but growth rate leveled off or ceased after $\approx 2$ months. Abbott and Gough (1987) reported that highbush blueberry maximum shoot growth coincided with the period of maximum root growth

Mulching reduces weed growth, helps maintain uniform soil moisture, promotes better soil structure, reduces soil erosion, and lowers soil temperatures in the summer (Darrow, 1957). Organic mulching lowered soil temperature at $15 \mathrm{~cm}$ below the soil surface $\approx 6 \mathrm{C}$ during the summer in southern Mississippi (Magee and Spiers, 1995). In rabbiteye blueberries, the major factor influencing root distribution in a sandy, well-aerated soil was soil moisture (Spiers, 1986). Incorporating peatmoss in the planting hole tended to concentrate roots near the crown area and at depths of 30 to $40 \mathrm{~cm}$. Mulching tended to concentrate the roots in the upper $15 \mathrm{~cm}$ of soil and resulted in more uniform root distribution from the crown outward. A commercial highbush blueberry planting in Arkansas yielded better when continuously mulched rather than

Received for publication 18 Nov. 1994. Accepted for publication 25 May 1995. The cost of publishing this paper was defrayed in part by the payment of page charges. Under postal regulations, this paper therefore must be hereby marked advertisement solely to indicate this fact.

HortScience, Vol. 30(5), August 1995 tures $(16,27$, and 38C) as main plots replicated five times and three clones each of two blueberry types as subplots with single-plant experimental units. These six plants (one plant/ clone/type) were uniformly spaced and randomly placed within each bed.

Greenhouse air temperatures from treatment initiation on 19 Nov. 1991 until late Mar. 1992 averaged 16 to $18 \mathrm{C}$, with a range of 14 to 24C. Throughout the study, substrate temperatures $(10-\mathrm{cm}$ depth) for the three treatments ranged as follows: $16 \pm 2,27 \pm 3$, and 38 $\pm 3 \mathrm{C}$. By the last of March, air in the greenhouse could not be maintained in the 16 to $21 \mathrm{C}$ range, and the experiment was terminated on 6 Apr. 1992. During the study, plants were uniformly fertilized twice weekly using a water-soluble solution containing: $1 \mu \mathrm{M}$ each of $\mathrm{N}, \mathrm{K}$, and $\mathrm{Mg}$ and $2 \mu \mathrm{M}$ of $\mathrm{Ca}$ plus minor elements. Additional watering was applied as needed to beds maintained at the higher temperatures. Data were analyzed by general linear models procedure (SAS Inst., 1985).

Visual ratings $(0=$ dead; $1=$ worst, but living; 5 = best plant) for plant shoot vigor were taken 3 days before study termination. At termination, plants were removed from the beds and their roots were washed. Roots were visually rated for vigor using the above system and root length (longest) was measured. New top and root growth were removed at the site of the original pruning, dried (60C), and weighed.

\section{Results and Discussion}

Substrate temperatures significantly $(P>$ 0.001 ) influenced shoot, root, and total plant growth; root length; and root and shoot vigor ratings (Table 1). No interactions that included temperature as a factor were significant.

All growth measurements decreased linearly as substrate temperature increased (Table 2). Shoot growth (dry weight) doubled with a decrease in substrate temperature from 38 to $27 \mathrm{C}$ and increased $1.5 \times$ with a decrease from 27 to $16 \mathrm{C}$. This relationship corresponded to shoot vigor rating increases of $2.3 \times$ and $1.4 \times$, with a decrease in temperatures from 38 to 27C and then to $16 \mathrm{C}$, respectively. Shoot growth was more than $3 \times$ greater with a substrate temperature at $16 \mathrm{C}$ than at $38 \mathrm{C}$.

Root growth (dry weight) increased 1.3×

Southern highbush and rabbiteye blueberry rooted cuttings were transplanted into 4-liter pots in Spring 1991 and grown outside with uniform cultural practices through the summer. Fifteen plants each of three clones of southern highbush (MS132, 'Magnolia', and 'Gulfcoast') and rabbiteye ('Climax', 'Premier', and 'Tifblue') were moved into a greenhouse (14-h daylength, air 16 \pm 3 C) in September. In early November, plants were removed from pots and the medium was washed from the roots. Measured from the crown, roots were pruned to $12 \mathrm{~cm}$ and tops removed at a height of $18 \mathrm{~cm}$. Plants were placed in $56-\mathrm{cm}$ (width) $\times 152-\mathrm{cm}$ (length) $\times 20-\mathrm{cm}($ depth $)$ aboveground beds. Each bed contained a thermostatically controlled heating mat (Pro-Grow Corp., Brookfield, Wis.) and 1 pine bark : 1 sand: 1 peat medium (by volume). Treatments consisted of three substrate (bed) tempera- with a decrease in substrate temperature from 38 to $27 \mathrm{C}$ (Table 2). Between 27 and 16C, root weight increased 1.6×. With substrate at $16 \mathrm{C}$, root growth was twice that at $38 \mathrm{C}$. Visual root vigor ratings were closely related to dry weight measurements. Root length followed the same relationship with substrate temperature as did dry weight and visual vigor ratings, but with less dramatic differences. As media temperatures decreased from 38 to $16 \mathrm{C}$, root length increased 1.6x. was similar for southern highbush and rabbiteye blueberries (Table 2) but did differ significantly between clones (Table 3). 'Gulfcoast' and 'Climax' had the most shoot growth and that of 'Gulfcoast' was significantly higher than for all other cultivars, except 'Climax'. Shoot growth of 'Climax' was significantly
Shoot growth, as measured by dry weight, 
Table 1. Significance of growth differences in blueberries ( $F$ value probability) due to substrate temperature (T), type (S), and clones within type [C (S)].

\begin{tabular}{|c|c|c|c|c|c|c|c|}
\hline \multirow{3}{*}{$\begin{array}{l}\text { Source } \\
\text { of } \\
\text { variation }\end{array}$} & \multirow[b]{3}{*}{ df } & \multicolumn{3}{|c|}{ New growth (dry wt in g) } & \multirow{3}{*}{$\begin{array}{l}\text { Root } \\
\text { length } \\
(\mathrm{cm})\end{array}$} & \multirow{2}{*}{\multicolumn{2}{|c|}{ Vigor rating $^{2}$}} \\
\hline & & \multirow[b]{2}{*}{ Shoot } & \multirow[b]{2}{*}{ Root } & \multirow{2}{*}{$\begin{array}{l}\text { Total } \\
\text { plant }\end{array}$} & & & \\
\hline & & & & & & Shoot & Root \\
\hline $\mathrm{T}$ & 2 & $* * *$ & $* * *$ & $* * *$ & $* * *$ & $* * *$ & $* * *$ \\
\hline S & 1 & NS & $* * *$ & $* * *$ & NS & NS & NS \\
\hline $\mathrm{C}(\mathrm{S})$ & 4 & $*$ & $*$ & $*$ & NS & $* * *$ & NS \\
\hline $\mathrm{T} \times \mathrm{S}$ & 2 & NS & NS & NS & NS & NS & NS \\
\hline $\mathrm{T} \times \mathrm{C}(\mathrm{S})$ & 8 & NS & NS & NS & NS & NS & NS \\
\hline
\end{tabular}

${ }^{2}$ Vigor ratings: $0=$ dead, $1=$ worst, $5=$ best vigor.

Ns, ${ }^{*}, * * *$ Nonsignificant or significant at $P>0.05$ and 0.001 , respectively.

Table 2. Influence of substrate temperature on growth of southern highbush (SHB) and rabbiteye (RE) blueberry.

\begin{tabular}{|c|c|c|c|c|c|c|}
\hline \multirow[b]{3}{*}{ Variable } & \multicolumn{3}{|c|}{ New growth (dry wt in g) } & \multirow{3}{*}{$\begin{array}{l}\text { Root } \\
\text { length } \\
(\mathrm{cm})\end{array}$} & \multirow{2}{*}{\multicolumn{2}{|c|}{ Vigor rating ${ }^{z}$}} \\
\hline & \multirow[b]{2}{*}{ Shoot } & \multirow[b]{2}{*}{ Root } & \multirow{2}{*}{$\begin{array}{l}\text { Total } \\
\text { plant }\end{array}$} & & & \\
\hline & & & & & Shoot & Root \\
\hline \multicolumn{7}{|c|}{ Temperature $\left({ }^{\circ} \mathrm{C}\right)$} \\
\hline 16 & 4.8 & 15.2 & 20.0 & 22.8 & 3.5 & 4.0 \\
\hline 27 & 3.2 & 9.7 & 12.9 & 20.4 & 2.5 & 2.5 \\
\hline 38 & 1.5 & 7.3 & 8.8 & 14.7 & 1.1 & 1.4 \\
\hline Linear & $* * *$ & $* * *$ & $* * *$ & $* * *$ & $* * *$ & $* * *$ \\
\hline \multicolumn{7}{|l|}{ Type } \\
\hline SHB & $3.8 \mathrm{a}^{\mathrm{y}}$ & $14.6 \mathrm{a}$ & $18.4 \mathrm{a}$ & $19.8 \mathrm{a}$ & $2.4 \mathrm{a}$ & $2.7 \mathrm{a}$ \\
\hline $\mathrm{RE}$ & $2.6 \mathrm{a}$ & $6.9 \mathrm{~b}$ & $9.5 \mathrm{~b}$ & $18.9 \mathrm{a}$ & $2.3 \mathrm{a}$ & $2.6 \mathrm{a}$ \\
\hline
\end{tabular}

${ }^{2}$ Vigor rating; $0=$ dead, $1=$ worst, $5=$ best vigor.

${ }^{y}$ Mean separation, LSD $_{0.05}$.

${ }^{* * *}$ Significant at $P>0.001$.

Table 3. Growth responses of six blueberry clones averaged over all substrate temperatures.

\begin{tabular}{|c|c|c|c|c|c|c|c|}
\hline \multirow[b]{3}{*}{ Types $y$} & \multirow[b]{3}{*}{ Clones } & \multicolumn{3}{|c|}{ New growth (dry wt in g) } & \multirow{3}{*}{$\begin{array}{l}\text { Root } \\
\text { length } \\
(\mathrm{cm})\end{array}$} & \multirow{2}{*}{\multicolumn{2}{|c|}{ Vigor rating $^{2}$}} \\
\hline & & & & Total & & & \\
\hline & & Shoot & Root & plant & & Shoot & Root \\
\hline \multirow[t]{3}{*}{ SHB } & MS132 & $2.9 b^{x}$ & $13.0 \mathrm{~b}$ & $15.9 \mathrm{~b}$ & $19.1 \mathrm{a}$ & $2.5 \mathrm{ab}$ & $2.9 \mathrm{a}$ \\
\hline & Magnolia & $3.0 \mathrm{~b}$ & $11.8 \mathrm{~b}$ & $14.8 \mathrm{~b}$ & $21.3 \mathrm{a}$ & $2.1 \mathrm{~b}$ & $2.6 \mathrm{a}$ \\
\hline & Gulfcoast & $5.5 \mathrm{a}$ & $18.9 \mathrm{a}$ & $24.4 \mathrm{a}$ & $18.8 \mathrm{a}$ & $2.6 \mathrm{ab}$ & $2.7 \mathrm{a}$ \\
\hline \multirow[t]{3}{*}{ RE } & Climax & $4.0 \mathrm{ab}$ & $9.8 \mathrm{~b}$ & $13.8 \mathrm{~b}$ & $20.3 \mathrm{a}$ & $2.7 \mathrm{ab}$ & $2.7 \mathrm{a}$ \\
\hline & Premier & $3.1 \mathrm{~b}$ & $7.4 \mathrm{bc}$ & $10.5 \mathrm{~b}$ & $19.2 \mathrm{a}$ & $3.1 \mathrm{a}$ & $2.9 \mathrm{a}$ \\
\hline & Tifblue & $0.7 \mathrm{c}$ & $3.6 \mathrm{c}$ & $4.3 \mathrm{c}$ & $17.1 \mathrm{a}$ & $1.2 \mathrm{~b}$ & $2.1 \mathrm{a}$ \\
\hline
\end{tabular}

${ }^{2}$ Vigor rating; $0=$ dead, $1=$ worst, $5=$ best vigor.

${ }^{y} \mathrm{SHB}=$ southern highbush; $\mathrm{RE}=$ rabbiteye.

${ }^{x}$ Mean separation, $\mathrm{LSD}_{0.05}$.

higher than for 'Tifblue' but did not differ from any other cultivar. Under field conditions, 'Tifblue' tends to grow more slowly than other rabbiteye cultivars during the first growing season (John Braswell, personal communication). In this study, shoot growth data and vigor ratings of shoots show this trend.

Root growth (dry weight) differed between types and clones within types (Table 1). Root growth of southern highbush was about double that of rabbiteye blueberries (Table 2). 'Gulfcoast' had significantly more root growth than any other clone (Table 3). 'Tifblue' had less root growth than all other clones but did not differ significantly from 'Premier'. The rest of the clones had about the same amount of root development. The differences found in dry weight measurements were not evident in root length or root vigor ratings.

Total plant (shoot and root) growth of southern highbush was twice that of rabbiteye blueberries (Table 2). 'Gulfcoast' had significantly more and 'Tifblue' produced signifi- cantly less total growth than any other clone (Table 3).

Root and shoot growth characteristics had high $(P>0.001)$ positive correlations (not shown). These findings are in agreement with those of Abbott and Gough (1987), who found growth of roots in highbush blueberries to be concomitant with shoot growth.

New shoot growth in 'Tifblue' was lowest with the $38 \mathrm{C}$ substrate, highest at $27 \mathrm{C}$, and intermediate at $16 \mathrm{C}$. With this exception, no quadratic relationships between plant growth attributes and substrate temperatures were significant.

Substrate temperature had highly significant influence on the shoot, root, and total growth of southern highbush and rabbiteye blueberries. All growth was best in a cool (16C) substrate and growth decreased as temperatures increased. In general, types and clones within types had similar responses to substrate temperatures. 'Gulfcoast', a southern highbush, was the most vigorous clone and
'Tifblue', a rabbiteye, the least. Reported type differences were mainly due to differences between these two clones.

When planted in mineral soils (using incorporated peatmoss and irrigation, but no mulch), southern highbush cultivars are usually less vigorous than rabbiteye cultivars (Makus et al., 1995). In my study, water stress was not a limiting factor. The substrate contained high amounts of organic matter and overall soil and air temperatures were lower than those found during the summer growing season in southern Mississippi (Magee and Spiers, 1995). Shoot growth of southern highbush clones was equal to or greater than that of the rabbiteye clones.

A previous study ranked individual cultural practices according to their production of dry root weight as follows: mulch > incorporated peatmoss > irrigation; plant root weight was correlated positively with plant growth and yield (Spiers, 1986). The present study indicates that the most beneficial influence of mulching on growth of blueberries in the southern United States may be its reduction of soil temperatures during the long, hot growing season. Cultural practices that cause a reduction in soil temperatures apparently promote root and shoot growth in southern highbush and rabbiteye blueberries.

\section{Literature Cited}

Abbott, J.E. and R.E. Gough. 1987. Seasonal development of highbush blueberry roots under sawdust mulch. J. Amer. Soc. Hort. Sci. 112:60-62.

Basiouny, F.M. and A.A. Powell. 1985. Effects of high temperature fertilization and irrigation on growth and leaf elemental contents of newly established rabbiteye blueberries. Proc. Fla. State Hort. Soc. 98:115-158.

Clark, J.R. and J.N. Moore. 1991. Southern highbush blueberry response to mulch. HorTechnology $1: 52-54$.

Darrow, G.M. 1957. Blueberry growing. U.S. Dept. Agr. Farmers' Bul. 1951 (revised).

Eck, P. 1988. Blueberry science. Rutgers Univ. Press, New Brunswick, N.J.

Lyrene, P.M. 1990. Low-chill highbush blueberries. Fruit Var. J. 44:82-86.

Magee, J.B. and J.M. Spiers. 1995. Influence of mulching systems on yield and quality of southern highbush blueberries. J. Small Fruit \& Viticult. (In press.)

Makus, D.J., J.M. Spiers, K.D. Patten, and E.W. Neuendorff. 1995. Growth responses of southern highbush and rabbiteye blueberry cultivars at three southern locations. J. Small Fruit \& Viticult. (In press.)

Moore, J.N. and G. Pavlis. 1979. Effect of organic mulches on highbush blueberry production in Arkansas. HortScience 14:129. (Abstr.)

SAS Institute. 1985. SAS/STAT guide for personal computers. Version 6 ed. SAS Inst., Cary, N.C.

Spiers, J.M. 1986. Root distribution of 'Tifblue' rabbiteye blueberry as influenced by irrigation, incorporated peatmoss, and mulch. J. Amer. Soc. Hort. Sci. 111:877-880.

Spiers, J.M. 1992. Establishment of 'Gulfcoast' southern highbush blueberry. HortScience 27:148. (Abstr.) 